\title{
DASAR-DASAR FILOSOFIS METODE PEMBELAJARAN BAHASA PRANCIS SEBAGAI BAHASA ASING DI INDONESIA
}

\author{
Siti Perdi Rahayu \\ Universitas Negeri Yogyakarta \\ email: siti_perdirahayu@uny.ac.id
}

\begin{abstract}
(Title: The Philosophical Foundations of the Learning Method of French as a Foreign Language in Indonesia). The aim of the current study is to describe the philosophical foundations used in learning French as a foreign language in Indonesia, specifically the language learning which refers to the CECR (Cadre Européen Commun de Rérence) or uniformity in learning, teaching and evaluation.This study adapts the qualitative descriptive method. The data are in the form of features and characteristics of actionnelle approach, pragmatism and analytical linguistic philosophy foundations. Data are taken from sources such as documents including books on actionnelle approach, Echo 1 and Echo 2 books. Data analysis is done by making a comparative description of the characteristics of the actionnelle approach with the implementation of the philosophy of pragmatism education and the philosophy of analytical linguistic education. The findings of this study indicate that: 1) pragmatism philosophy implies that education at every level must have criteria to be utilized and applied in social life because students are indeed social actors, 2) analytical linguistic philosophy has the principle that word meanings are in sentences, meaning of sentences in language, and the meaning of language exists in various life contexts, and 3) actionnelle approach is characterized by action, assimilating students as language users and as social actors who have tasks to do. The existence of the mentioned similarities can lead us to conclude that the actionnelle approach gained influence from the philosophy of pragmatism and analytical linguistics.
\end{abstract}

Keywords: actionnelle approach; pragmatism philosophy; analytical linguistic philosophy.

\section{PENDAHULUAN}

Pada dasarnya filsafat dan pendidikan mempunyai hubungan yang sangat erat. Sebab, pada hakekatnya pendidikan merupakan suatu proses pewarisan nilai-nilai filsafat. Nilainilai inilah yang harus selalu dikembangkan agar dapat memenuhi kebutuhan hidup dan kehidupan yang lebih baik dari kondisi sebelumnya. Dalam pendidikan selalu dibutuhkan filsafat pendidikan agar arah pendidikan dapat diterima secara rasional. Filsafat pendidikan adalah ilmu yang mempelajari dan berusaha mengadakan penyelesaian terhadap masalahmasalah pendidikan yang bersifat filosofis. Masalah-masalah tersebut diantaranya adalah tujuan pendidikan yang bersumber dari tujuan hidup manusia dan nilai sebagai pandangan hidup manusia (Sadulloh, $2014: 8$ ).

Salah satu bentuk pendidikan adalah pembelajaran bahasa Asing. Dalam pembela- jaran bahasa terdapat proses belajar mengajar (PBM), yang memiliki berbagai unsur yang wajib ada. Unsur-unsur tersebut diantaranya adalah guru/pengajar, siswa/pembelajar, rencana pembelajaran, pendekatan/metode pengajaran, media pengajaran dan evaluasi pembelajaran. Dalam pembelajaran bahasa asing, utamanya bahasa Prancis, tentunya juga harus ada unsur-unsur tersebut. Salah satu unsur yang dibutuhkan adalah sebuah pendekatan atau metode pengajaran, yaitu bagaimana mengajarkan bahasa asing kepada pembelajar, agar tujuan pengajaran itu dapat tercapai dengan hasil yang baik. Berdasarkan perkembangannya, pendekatan dalam pembelajaran bahasa asing mengalami beberapa perkembangan atau kemajuan. Secara terus menerus, para ahli melakukan inovasi-inovasi di bidang pembelajaran kelas, khususnya kelas bahasa asing, lebih khusus lagi kelas bahasa Prancis. Pembe- 
lajaran bahasa Prancis sebagai bahasa asing di Indonesia sudah dilakukan sejak tahun 1952, beberapa tahun setelah Indonesia merdeka (Dwidjosusastro, 1995: 155)

Bahasa Prancis sudah diajarkan mulai dari tingkat SMA/SMK/MA maupun di tingkat perguruan tinggi, baik di sekolah/perguruan tinggi negeri maupun swasta. Bahkan pada bulan Februari 2008, telah disepakati bersama oleh 10 Universitas di Indonesia yang menyelenggarakan pembelajaran bahasa Prancis, seperti: UNY, UNJ, UPI, UGM, UI, UNIMED, UNHAS, UNNES, dan UNPAD, terhadap standar kompetensi yang dituntut untuk lulusan S1 Pendidikan Bahasa Prancis maupun Sastra Prancis seluruh Indonesia. Kesepakatan itu adalah keterampilan berbahasa untuk lulusan S1 harus setingkat B2. Jadi, seseorang yang memiliki kemampuan berbahasa Prancis tingkat B2, dia akan memiliki tingkat kemandirian yang memadai. Dengan kompetensi ini seseorang tidak akan mendapatkan kesulitan jika melanjutkan studi di Prancis atau negaranegara berbahasa Prancis (Francophone). Hal ini juga yang dipersyaratkan bagi universitasuniversitas di Prancis untuk menerima mahasiswa asing. Dalam masa sejak awal pembelajaran sampai sekarang, beberapa pendekatan dan metode pernah diterapkan dalam pembelajaran bahasa Prancis sebagai bahasa asing di Indonesia, seperti metode tata bahasa-terjemahan, metode audio-oral, metode langsung, dan pendekatan komunikatif (Enrica Piccardo, 2014:9). Buku-buku ajar yang digunakan pun juga mengalami penyesuaian dengan metode pembelajaran tersebut, seperti : buku De ViveVoix, La France Direct, dan Intercode cenderung meggunakan metode audio-oral dan metode langsung, sedangkan buku, Tempo, dan Campus cenderung menggunakan pendekatan komunikatif.

CECR adalah sebuah dokumen resmi Dewan Uni Eropa (conseild'Europe) yang diterbitkan oleh Divisi Politik Bahasa (Division des Politiques Linguistique) yang berkantor di Strasbourg, Prancis. Dokumen yang dibuat pada tahun 1991 dan mulai dipublikasikan pada tahun 2001 ini merupakan kerangka acuan untuk belajar (apprendre), mengajarkan (enseigner), dan melakukan evaluasi (évaluer) dalam pengajaran / pendidikan bahasa-bahasa di lingkungan / Negara-negara Uni Eropa. Dan tentu saja penyusunan kerangka acuan ini disesuaikan dengan kebutuhan politik bahasa di Negara-negara tersebut (Enrica Piccardo, 2014:6). Salah satu buku ajar yang digunakan untuk pembelajaran bahasa Prancis di Indonesia adalah Echo 1, 2, dan 3.

Pembelajaran bahasa Prancis di Indonesia pun harus mengacu kepada konsep yang telah ditentukan dalam CECR, yaitu adanya penyeragaman dalam pembelajaran, pengajaran dan evaluasi (bahasa negara-negara Eropa). Di Indonesia, untuk bidang studi bahasa Prancis, konsep atau kerangka CECR ini dikenal melalui ujian DELF dan DALF. Salah satu hal yang sering didengungkan oleh konsep ini adalah kesadaran akan pentingnya menjembatani perbedaan budaya ketika sebuah komunikasi terjadi. Pendekatan yang ditawarkan oleh CECR dalam pembelajaran bahasa Prancis adalah pendekatan actionnelle (approche actionnelle), yaitu pendekatan komunikatif yang berbasis tindakan. Pendekatan komunikatif dalam hal ini menekankan pada komunikasi dan menempatkan pembelajar sebagai pusat proses pembelajaran, membuatnya aktif, mandiri dan bertanggungjawab pada kemajuannya, sedangkan pendekatan actionnelle mengambil semua konsep pendekatan komunikatif dan menambahkan strategi yang berupa tâche "tugas" dengan konteks yang beragam (hal-hal yang akan dihadapi pembelajar dalam kehidupan sosial). Pendekatan ini menempatkan pembelajar sebagai aktor sosial yang mampu menggunakan serangkaian kemampuan termasuk unsur strategis, kognitif, verbal maupun non verbal untuk mencapai keberhasilan komunikasi (Tagliante, 2002: 36). Pada proses pembelajaran, pembelajar tidak diberi latihan-latihan, tetapi pembelajar diberi tugas 'tâche', misalnya tugas kreatif, tugas yang berkaitan dengan ketrampilan, tugas pemecahan masalah, tugas melakukan presentasi, dan tugas-tugas lain yang dapat ditemui dalam kehidupan sehari-hari. Para pembelajar tidak lagi dituntut mereproduksi dan memproduksi pola kalimat-pola kalimat yang kaku, tetapi harus disesuaikan dengan situasi dan kondisi (Enrica Piccardo, 2014:13). 
Penggunaan pendekatan actionnelle ini tentu memiliki landasan filosofis, sehingga dapat ditetapkan sebagai pendekatan yang harus dipakai dalam pembelajaran bahasa Prancis sebagai bahasa asing, terutama di Indonesia. Dari sudut pandang filosofis, Pembelajaran bahasa Prancis saat ini membuat pembelajar beralih dari manusia yang berkomunikasi ke manusia yang bertindak. Sebagaimana telah disebutkan sebelumnya, inilah yang menjadi ciri khas pendekatan actionnellle, yaitu pembelajaran bahasa yang bertujuan mempersiapkan pembelajar tidak hanya mampu berkomunikasi melainkan juga berpartisipasi atau bertindak dalam kehidupan sosial. Untuk mendukung pembelajaran dengan pendekatan actionnelle tentu juga dibutuhkan materi atau bahan ajar yang sesuai, salah satu contoh bahan ajar atau materi yang menawarkan pembelajaran bahasa dengan pendekatan actionnelle adalah buku ajar (bhs Prancis : méthode) "Echo", yang terdiriatas Echo 1, Echo 2, dan Echo 3.

ECHO adalah semacam buku ajar untuk pembelajaran bahasa Prancis sebagai bahasa asing dengan menggunakan pendekatan actionnelle. Hal ini sesuai dengan yang dijelaskan oleh pengarang buku itu, J. Pécheur et J. Girardot

"Echo est une méthode français langue étrangère qui s'adresse à de grands adolescents et à des adultes débutants ou faux débutants. Elle est conçue à partir de supports variés qui reflètent les intérêts et les préoccupations de ce public. Elle s'appuie le plus possible sur des activités naturelles plus proches de la conversation entre adultes que de l'exercice scolaire. Elle cherche aussi à concilier le dosage obligé des difficultés avec le besoin de posséder très vite les clés de la communication et de s'habituer à des environnements linguistiques riches (Girardet, $\mathrm{J}$ et $\mathrm{J}$. Pécheur. 2008: 2)

Secara garis besar buku ECHO adalah buku atau metode pembelajaran bahasa Prancis yang ditujukan kepada pembelajar bahasa Prancis usia remaja dewasa atau pemula. Buku ini dirancang dan disesuaikan dengan keinginan pembelajar, berisi tentang materi-materi yang berupa kegiatan-kagiatan yang bersifat alamiah (natural) yang cenderung terjadi pada remaja dewasa. Buku ini juga berusaha memberikan kemudahan-kemudahan untuk dapat berkomunikasi dengan cepat dan membiasakan diri menyesuaikan dengan lingkungan yang sarat dengan konteks kebahasaan.

Filsafat pendidikan selalu mempunyai andil besar dalam penentuan arah sebuah pendidikan, termasuk di dalamnya pembelajaran bahasa Prancis. Ada berbagai macam aliran filsafat pendidikan antara lain: filsafat pendidikan Pragmatisme, filsafat pendidikan Idealisme, filsafat pendidikan Progresivisme, filsafat pendidikan Realisme, filsafat pendidikan Eksistensialisme, filsafat pendidikan Perenialisme, filsafat pendidikan esensialisme, filsafat pendidikan rekonstruksionisme, dan filsafat pendidikan analitik. Dalam penelitian ini, tidak semua aliran filsafat tersebut dibahas. Sebenarnya tidak ada suatu pendidikan yang hanya berlandaskan pada salah satu filsafat saja, karena masing-masing aliran mempunyai kelebihan dan kekurangan, sehingga kadang-kadang dibutuhkan landasan filosofis yang bersifat eklektik, yaitu landasan filsafat yang bersifat campuran, memilih ajaran-ajaran yang baik-baik saja dan yang cocok dengan tujuan pendidikan yang dipilih. Oleh karena itu, dalam penelitian ini hanya akan diuraikan tentang filsafat pendidikan pragmatis dan filsafat pendidikan analitik, yang diduga menjadi dasar filosofis metode pembelajaran bahasa Prancissebagai bahasa asing di Indonesia.

Sesuai dengan penjelasan tentang aliran filsafat pendidikan pragmatis dan analitik tersebut, benarkah pendekatan actionnelle sebagai pendekatan dalam pembelajaran bahasa Prancis sebagai bahasa asing mendapat pengaruh dari ajaran-ajaran yang ada dalam filsafat pendidikan pragmatisme dan analitik linguistik tersebut. Buku ajar atau méthode yang menjadi sampel penelitian adalah buku Écho, yang terdiri dari Echo 1 dan 2. Bukubuku ini sudah menerapkan pendekatan $a c$ tionnnelle. Alasan pemilihan buku ini dipakai sebagai subjek penelitian, karena pengalaman peneliti sebagai pengajar bahasa Prancis juga telah menerapkan pendekatan actionnelle dengan menggunakan buku-buku tersebut. 


\section{PEMBAHASAN}

Untuk menemukan dasar-dasar filosofis yang digunakan dalam pendekatan $a c$ tionnelle yang diterapkan dalam pembelajaran bahasa Prancis sebagai bahasa asing, diuraikan terlebih dahulu aliran-aliran filsafat yang mempengaruhi pendekatan actionnelle tersebut.

\section{Aliran Filsafat Pendidikan Pragmatis}

Istilah pragmatisme berasal dari kata 'pragma' yang berarti praktik atau berbuat atau bertindak. Maksudnya adalah bahwa makna segala sesuatu tergantung pada hubungannya dengan apa yang dilakukan. Pragamatisme memberikan sumbangan yang sangat besar terhadap teori pendidikan. John Dewey merupakan tokoh pragmatisme yang secara eksplisit membahas pendidikan dan secara sistematis menyusun teori pendidikan yang didasarkan atas filsafat pragmatisme (Sadulloh, 2014:124). Selanjutnya, Dewey menjelaskan tentang konsep pendidikan, yaitu adanya dua teori pendidikan yang saling bertentangan antara yang satu dengan yang lainnya. Kedua teori pendidikan tersebut dikenal dengan istilah paham konservatif dan Unfolding theory (teori pemerkahan). Paham konservatif menyatakan bahwa pendidikan adalah sebagai suatu pembentukan terhadap pribadi anak tanpa memperhatikan kekuatan-kekuatan atau potensi-potensi yang ada dalam diri anak. Jadi pendidikan akan menentukan segalanya, artinya pendidikan merupakan suatu proses pembentukan jiwa dari luar. Mata pelajaran ditentukan menurut kemauan pendidik, sehingga siswa tinggal menerima saja. Sedangkan Unfolding theory (teori pemerkahan) adalah bahwa anak akan berkembang dengan sendirinya, karena ia telah memiliki kekuatan-kekuatan laten (tersembunyi), dimana perkembangan sianak telah mempunyai tujuan yang lengkap dan pasti. Namun bukan dua teori ini yang dimaksud oleh Dewey, tetapi dia menjelaskan bahwa pendidikan menurut prgmatisme adalah suatu proses reorganisasi dan rekonstruksi dari pengalaman-pengalaman individu, baik anak maupun orang dewasa selalu belajar dari pengalamnnya. Akhirnya John Dewey menyimpulkan akan pentingnya pendidikan karena didasarkan pada tiga pokok pemikiran: (1) pendidikan merupakan kebutuhan untuk hidup, (2) pendidikan sebagai pertumbuhan, dan (3) pendidikan sebagai fungsi sosial (Sadulloh, 2014:124-125).

Dalam pelaksanaannya, filsafat pendidikan pragmatisme mengarahkan agar subjek didik atau pembelajar saat belajar di sekolah tak berbeda ketika ia berada di luar sekolah. Oleh karenanya, kehidupan di sekolah selalu disadari sebagai bagian dari pengalaman hidup, bukan bagian dari persiapan untuk menjalani hidup. Di sini pengalaman belajar di sekolah tidak berbeda dengan pengalaman saat ia belajar di luar sekolah. Pembelajar menghadapi problem yang menyebabkan lahirnya tindakan penuh dari pemikirannya. Di sini kecerdasan disadari akan melahirkan pertumbuhan, dan pertumbuhan akan membawa mereka di dalam beradaptasi dengan dunia yang berubah. Ide gagasan yang berkembang menjadi sarana keberhasilan.

Implikasi filsafat pendidikan pragmatisme terhadap pelaksanaan pendidikan dapat diuraikan sebagai berikut sebagaimana yang dijelaskan oleh Power (1982) (melalui Sadulloh, 2014: 133), sebagai berikut. Pertama, tujuan pendidikan adalah memberi pengalaman untuk penemuan hal-hal baru dalam hidup sosial dan pribadi. Kedua, kedudukan Siswa: Siswa adalah suatu organisme yang mempunyai kemampuan yang luar biasa dan kompleks untuk tumbuh. Ketiga, kurikulum berisi pengalaman yang teruji dan yang dapat diubah. Minat dan kebutuhan siswa yang dibawa ke sekolah dapat menentukan kurikulum. Menghilangkan perbedaan antara pendidikan liberal dengan pendidikan praktis atau pendidikan jabatan. Keempat, metode: Metode aktif, yaitu learning by doing (belajar sambil bekerja atau bertindak). Kelima, peran guru. Guru memiliki peran untuk mengawasi dan membimbing pengalaman belajar siswa, tanpa mengganggu minat dan kebutuhannya.

\section{Aliran Filsafat Pendidikan Analitik}

Menurut Lorens Bagus (1996:249) filsafat analitik merupakan suatu ungkapan yang menghimpun semua karya filsafati abad XX yang bersandar kuat pada analisis linguistik dan analisis logis. Dalam pandangan penulis filsafat (Wicoyo, 1997:4) dan Mustansyir 
(2007: 44-124), filsafat analitik terbagi dalam tiga aliran pemikiran filsafat bahasa yaitu atomisme logik (logical atomisme), positivisme logik (logical positivism), dan filsafat bahasa biasa (the ordinary language philosophy).

Bagian ketiga dari filsafat analitik adalah filsafat bahasa biasa (the ordinary language philosophy), memiliki tiga tokoh utama. Ketiga tokoh tersebut adalah Ludwig Wittgeinstein II (1889-1951), Gilbert Ryle (1900-1976) dan John Langshaw Austin (1911-1960). Model analitik ini terbagi dua golongan, yaitu analitik linguistik dan analitik positivistik logis. Model analitik linguistik mengandung arti bahwa filsafat sebagai analisis logis tentang bahasa dan penjelasan makna istilah. Para filosof memakai metode analitik linguistik untuk menjelaskan arti suatu istilah dan pemakaian bahasa.

Pendekatan analitik linguistik memusatkan perhatiannya pada analisis bahasa, kata-kata, istilah-istilah, dan pengertianpengertian dalam bahasa. Dengan pendekatan analitik linguistik, akan diuji suatu ide atau gagasan, seperti : istilah/ ide kebebasan akademik, hak asasi manusia, demokrasi, potensi anak dan sebagainya. Pendekatan ini lebih bertujuan mengklarifikasi bahasa dan pemikiran yang ada daripada membuat pendapat-pendapat yang baru tentang hakikat kenyataan. Pendekatan analitik linguistik akan menjelaskan pernyataan-pernyataan spekulatif dan preskriptif. Misalnya kita memperkenalkan konsep cara belajar siswa aktif. Dengan menggunakan tata bahasa dan logika kita kaji konsep tersebut dengan cara menganalisis dari sudut pandang kehidupan nyata. Pendekatan Analitik Linguistik menguji secara logis konsep-konsep pendidikan, seperti manusia seutuhnya sebagai tujuan pendidikan, pendidikan seumur hidup, pendidikan akademik, kewibawaan, dan sebagainya. Filsafat analitik linguistik bukan merupakan suatu bangunan pengetahuan, melainkan merupakan suatu aktivitas yang bertujuan menjernihkan istilah-istilah yang dipergunakan dalam kehidupan nyata. Bahasa dalam kehidupan sehari-hari digunakan dengan berbagai cara untuk mengungkap banyak hal.

Inti pemikiran Wittgenstein II adalah tata permainan bahasa (Language-Games). Hakikat bahasa adalah penggunaannya dalam berbagai macam konteks kehidupan manusia. Setiap konteks kehidupan manusia menggunakan satu bahasa tertentu yang memiliki aturan penggunaan tertentu yang berbeda dengan konteks penggunaan lainnya. Singkatnya setiap konteks kehidupan memiliki aturan penggunaan bahasa yang berbeda-beda. Wittgensein pada pemikiran ini menyimpulkan bahwa makna sebuah kata adalah penggunaannya dalam kalimat, makna sebuah kalimat adalah penggunaannya dalam bahasa, dan makna bahasa adalah penggunaannya dalam berbagai konteks kehidupan manusia (Mustansyir, 2007: 101-106)

\section{Buku Echo dan Dasar Fiosofinya}

Ada tiga perspektif pembelajaran dalam buku Echo yang menggunakan pendekatan actionnelle, yaitu: (1) Pembelajaran bahasa akan diadaptasikan pada konteks situasional yang disesuaikan dengan bidang yang menarik bagi siswa, (2) Siswa akan menjadi aktor sosial di kelas. Kelas akan menjadi ruang sosial yang secara alami siswa dapat menjalani banyak tugas dan melakukan simulasi tugas-tugas yang harus dilakukan ketika siswa berada di negara Prancis atau di negara berbahasa Perancis, dan (3) Untuk memperoleh keterampilan, siswa akan menjadi pemain dalam pembelajarannya sendiri bersama-sama dengan kelompok kelas.

Buku metode ini mengatur pembelajaran sesuai dengan konteks situasional yang harus diadaptasi oleh siswa. Konteks inilah yang menentukan tugas yang harusdiselesaikan siswa. Setiap konteks dalam buku tersebut sesuai dengan satu unit metode, unit ini mewakili antara 30 hingga 40 jam pengajaran. Dalam setiap unit (konteks situasional) tugas-tugas diatur dalam dua cara: 1) Secara integratif artinya semua siswa dan pengajar harus mengetahui konteks situasi tertentu. Misalnya, untuk berintegrasi ke dalam lingkungan professional, seseorang harus belajar mencari pekerjaan, mengelola hubungan dengan kolega, hierarki, serikat pekerja dan masyarakat, berbicara tentang suatu produk, menggambarkan dan mengevaluasi proyek pembangunan ekonomi, dan 2) Narasi rencana pembelajaran dalam bentuk skenario aksi. Misalnya untuk mencari pekerjaan siswa harus mencari tawaran pekerjaan, 
mengirim $\mathrm{CV}$ dan surat lamaran, berpartisipasi dalam wawancara, dll.

Urutan pembelajaran dalam buku Echo tersebut jelas mengikuti level-level (niveaux) yang dianjurkan oleh CECR. Buku Echo mencakup empat level (A1, A2, B1, dan B2). Dalam perspektif tindakan, CECR mengasimilasi siswa sebagai pengguna bahasa. Keduanya adalah aktor sosial yang memiliki tugas untuk dilakukan. Di kelas bahasa akan ada tiga jenis tugas: (1) tugas-tugas yang dapat digambarkan sebagai alami karena mereka secara alami dibangkitkan oleh kelompok sosial kelas, (2) tugas yang disimulasikan, dan (3) tugas teknis atau tugas belajar.

Namun demikian beberapa latihan dapat menjadi tugas jika memenuhi kondisi berikut. Pertama, latihan-latihan tersebut sesuai dengan minat yang berasal dari siswa. Sebagai contoh, dua siswa menginginkan menghafal dan mengotomatisasikan konjugasi kala kini (présent) beberapa verba. Dibuatlah teknik kreatif dengan membuat dialog kecil. Dengan cara ini siswa kemudian menyadari apa yang dia lakukan dan mengapa dia melakukannya. Kedua, Latihan ini didukung oleh teks-teks kecil atau dialog yang memiliki arti yang sama dengan dokumen lain yang ada di dalam buku Echo. Latihan-latihan tersebut menarik memunculkan reaksi (action). Kedua, tata bahasa atau kosa kata dipelajari sesuai dengan pedagogi penemuan yang membuat siswa aktif. Aturan tidak diberikan kepada siswa, terserah kepada siswa untuk menyimpulkannya dari kegiatan konkret, identifikasi dan klasifikasi.

Dari awal pertemuan dalam kelas bahasa Prancis, menurut buku Echo, pembelajar sudah menjadi aktor sosial. Kelas menjadi ruang sosial yang di dalamnya pembelajar akan mendapat informasi, dan saling bertukar pengalaman dan pendapat. Dari interaksi ini akan muncul keinginan untuk menguasai kosa kata, tata bahasa dan pengucapan, kebutuhan untuk memperoleh strategi pemahaman dan produksi, dan keinginan untuk lebih memahami budaya Francophone. Pada saat yang sama, kegiatan simulasi akan memungkinkan peserta didik (pebelajar) untuk mengantisipasi situasi yang harus mereka jalani di lingkungan Francophone. Pada akhir setiap unit dalam buku
Echo, pembelajar melanjutkan dengan guru untuk meninjau kembali pengetahuan dan keterampilannya. Ada lembar evaluasi yang memungkinkan untuk mengontrol pemerolehan diri di akhir setiap pelajaran. Dalam lembaran itu, pembelajar akan mencatat berbagai kegiatan pembelajarannya serta kemajuannya dalam hal pengetahuan dan keterampilan.

Dengan menghadirkan beberapa contoh prosedur kerja berbasis tugas ini, baik secara garis besar maupun rinci, buku Echo yang didalamnya terdapat aplikasi pendekatan actionnelle dapat ditemukan poin-poin yang sama dengan ciri-ciri aliran filsafat pendidikan pragmatisme. Hal tersebut dapat dilihat pada proses pendidikan sesuai konsep aliran filsafat pendidikan pragmatisme. Proses pendidikan menurut pragmatisme adalah jika pelajaran yang diberikan kepada siswa didasarkan pada fakta-fakta yang sudah diobservasi, dipahami, serta dibicarakan sebelumnya. Bahan pelajaran harus mengandung ide-ide yang dapat mengembangkan situasi untuk mencapai tujuan dan harus ada hubungannya dengan materi pelajaran. Pendidikan dalam setiap tingkatan harus memiliki kriteria untuk memanfaatkan kehidupan sosial, karena siswa memang aktor sosial.

Bahan pelajaran terdiri atas seperangkat tindakan untuk memberi isi kepada kehidupan sosial yang ada pada waktu itu. Siswa harus mempelajari dunia dimana dia hidup. Jadi sekolah merupakan cara khusus untuk mengatur lingkungan, direncanakan dan diorganisasi. Di sekolah siswa belajar apa yang ada dalam kehidupan, sekolah juga harus menjadi tempat dimana kehidupan berlangsung. Dengan sekolah pengajar dapat menolong siswa dalam menciptakan kehidupan yang baik, dan sekolah tidak dipisahkan dari kehidupan. Pendidikan adalah kehidupan itu sendiri bukan persiapan untuk suatu kehidupan. Materi pelajaran harus berhubungan langsung dengan masalah yang dihadapi anak. Dengan demikian, dapat disimpulkan bahwa pendekatan actionnelle yang ada dalam buku Echo sangat cocok dengan konsep pendidikan yang dipaparkan oleh aliran pendidikan pragmatisme.

Selanjutnya, di samping filsafat pragmatisme, pendekatan actionnelle juga menda- 
pat pengaruh dari filsafat analitik, khususnya analitik linguistik. Pendekatan analitik linguistik menguji secara logis konsep-konsep pendidikan seperti konsep tentang manusia seutuhnya, tujuan pedidikan, pendidikan seumur hidup, kedewasaan, dan lain sebagainya. Secara singkat filsafat analitik linguistik menyatakan bahwa guru-guru seharusnya memberikan pengalaman kehidupan nyata pada siswa atau kurikulum seharusnya didasarkan pada situasi kehidupan yang sebenarnya. Pertama, pernyataan-pernyataan ini seharusnya dikenal sebagai preskriptif. Kedua, istilah-istilah deskriptif tentang pengalaman kehidupan nyata dan seperti kehidupan yang sebenarnya harus diuji untuk menetukan artinya. Istilah kehidupan merupakan suatu deskripsi dari seluruh aktivitas umat manusia. Salah satu aktivitas umat manusia yang sekarang adalah mentasrifkan/ mengkonjugasikan verba (kata kerja). Namun demikian ketika pernyataan ini seringkali digunakan, maka istilah mentasrifkan verba (kata kerja) bukanlah hal yang seperti dimaksudkan, untuk latihan-latihan tata bahasa bukanlah dianggap seperti kehidupan sebenarnya, tetapi tata bahasa merupakan bagian dari kehidupan

Dari sudut filsafat analitik linguistik, pendekatan actionnelle pada buku Echo merupakan aplikasi dari konsep pendidikan yang menyatakan bahwa "guru-guru seharusnya memberikan pengalaman kehidupan nyata pada siswa'. Dalam pendekatan actionnelle, proses belajar mengajar jelas memberikan pe- ngalaman tentang kehidupan nyata, karena dalam pembelajaran dengan pendekatan actionnelle siswa berperan sebagai aktor sosial atau pemeran sosial. Filsafat analitik linguistik juga menyebutkan bahwa salah satu aktivitas umat manusia yang sekarang adalah mentasrifkan verba (kata kerja). Verba (kata kerja) yang dimaksud di sini adalah melakukan sebuah tindakan, tindakan yang merupakan bagian dari kehidupan.

Dengan demikian, cocok dengan pendekatan actionnelle yang menekankan pada aspek tindakan. Jika digambarkan dalam sebuah bagan, hubungan antara filsafat pragmatisme dan analitik linguistik terhadap pendekatan $a c$ tionnelle dalam pembelajaran bahasa Prancis sebagaimana tersaji pada Bagan 1.

Selanjutnya, hal-hal yang menjadi kesamaan antara pragmatisme, analitik linguistik dan pendekatan actionnelle dapat dilihat pada Tabel 1.

\section{SIMPULAN}

Berdasarkan pembahasan tentang pendekatan actionnelle, aliran filsafat pendidikan pragmatisme dan juga aliran filsafat pendidikan analitik, dapat ditemukan hasilhasil sebagai berikut. Pendekatan actionnelle yang diaplikasikan dalam buku Echo adalah pendekatan dalam pembelajaran bahasa Prancis yang merupakan perpaduan pendekatan komunikatif dengan ditambahkan sebuah tindakan dalam kehidupan nyata. Sementara itu,

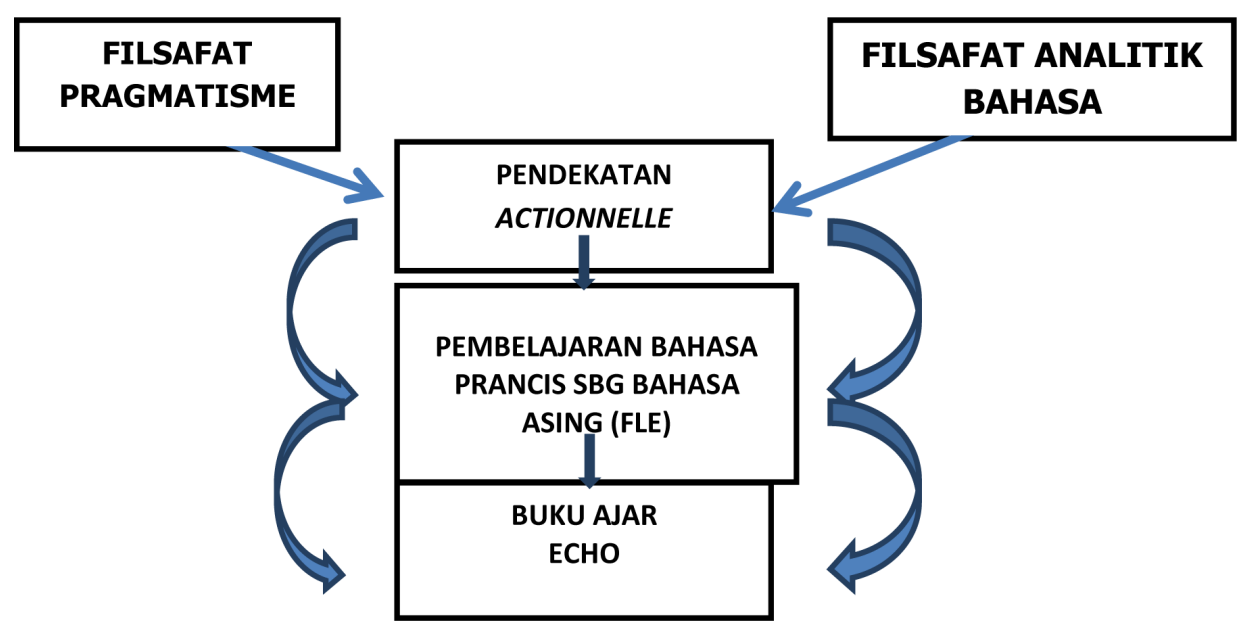

Bagan 1. Pengaruh filsafat pragmatisme dan analitik bahasa terhadap Pembelajaran Bahasa Prancis sebagai bahasa asing 
Tabel 1. Poin-poin yang menunjukkan adanya pengaruh filsafat pragmatisme dan filsafat analitik bahasa terhadap pendekatan actionnelle

\begin{tabular}{|c|c|c|}
\hline Pendekatan Actionnelle & Filsafat Pragmatisme & Filsafat Analitik Bahasa \\
\hline $\begin{array}{l}\text { pengajaran bahasa tidak cukup } \\
\text { hanya pada tataran linguistik, } \\
\text { tetapi mutlak perlu memasukkan } \\
\text { aspek pragmatik, sosiolinguistik } \\
\text { dan sosiokultural di dalamnya }\end{array}$ & $\begin{array}{l}\text { pengalaman langsung dianggap } \\
\text { lebih memotivasi karena } \\
\text { memiliki nilai instrinsik, } \\
\text { dan lebih bermakna karena } \\
\text { melibatkan subjek didik dalam } \\
\text { pengalaman langsung. Mis : } \\
\text { seseorang akan lebih banyak } \\
\text { belajar tentang pembuatan susu } \\
\text { dan sapi, peran dengan pergi ke } \\
\text { perusahaan pembuatan susu dan } \\
\text { memerah susu, membaunya, } \\
\text { mendengar suara sapi, dan } \\
\text { sebagainya }\end{array}$ & $\begin{array}{l}\text { mendasarkan kepada bahasa } \\
\text { sehari-hari, yaitu bahasa yang } \\
\text { dipakai dalam kehidupan } \\
\text { sehari-hari (ordinary } \\
\text { language) } \\
\text { - Kondisi praktis tindak } \\
\text { komunikasi menjadi pijakan } \\
\text { utama }\end{array}$ \\
\hline $\begin{array}{l}\text { menempatkan pembelajar, } \\
\text { subjek pengguna bahasa sebagai } \\
\text { "aktorsosial" yang harus } \\
\text { melakukan berbagai tindakan } \\
\text { dengan tuturan dalam berbagai } \\
\text { situasisosial }\end{array}$ & $\begin{array}{l}\text { Model pembelajaran adalah anak } \\
\text { belajar di dalam kelas dengan } \\
\text { cara berkelompok }\end{array}$ & $\begin{array}{l}\text { pembelajaran bahasa tidak } \\
\text { didasarkan pada struktur } \\
\text { melainkan didasarkan pada } \\
\text { pemakaian bahasa sesuai } \\
\text { konteksnya dalam komunikasi } \\
\text { sehari. }\end{array}$ \\
\hline $\begin{array}{l}\text { Dalam pengajaran tata bahasa } \\
\text { tidak lagi diajarkan dalam mata } \\
\text { kuliah khusus tersendiri dengan } \\
\text { latihan-latihan sistematisasi } \\
\text { struktur, tapi dihadirkan } \\
\text { dalam konteks situasi-situasi } \\
\text { interaksi sosial dan tindak- } \\
\text { tutur kontekstual nyata dalam } \\
\text { keseharian masyarakat yang } \\
\text { menggunakan bahasa } \\
\text { tersebut. }\end{array}$ & $\begin{array}{l}\text { - Guru menyesuaikan bahan } \\
\text { ajar sesuai dengan minat dan } \\
\text { kebutuhan anak tersebut, } \\
\text { - Ruang kelas (yang dilihat } \\
\text { tidak hanya sebagai sebuah } \\
\text { setting 'sekolah', melainkan } \\
\text { juga tempat dimana segala } \\
\text { pengalaman belajar dapat } \\
\text { diselenggarakan) }\end{array}$ & \\
\hline $\begin{array}{l}\text { guru hanya bertindak sebagai } \\
\text { fasilitator dan motivator }\end{array}$ & $\begin{array}{l}\text { guru hanya bertindak sebagai } \\
\text { fasilitator dan motivator }\end{array}$ & \\
\hline
\end{tabular}

aliran filsafat pragmatif juga menekankan bahwa pendidikan dalam setiap tingkatan harus memiliki kriteria untuk memanfaatkan kehidupan sosial, karena siswa memang aktor sosial. Filsafat analitik, khususnya analitik linguistik ini lebih bertujuan mengklarifikasi bahasa dan pemikiran yang ada daripada membuat pendapat-pendapat yang baru tentang hakikat kenyataan. Pendekatan analitik linguistik akan menjelaskan pernyataan-pernyataan spekulatif dan preskriptif, bahwa setiap bahasa atau istilah harus dijelaskan preskriptif maupun deskriptif, sesuai dengan tindakan-tindakan yang ada dalam kehidupan nyata.
Simpulan yang dapat ditarik dari hasilhasil sebagai berikut. Pertama, pembelajaran bahasa Prancis di Indonesia harus mengacu kepada konsep yang telah ditentukan dalam CECR. Kedua, pembelajaran bahasa Prancis di Indonesia menerapkan pendekatan actionnelle dalam proses belajar mengajarnya. Ketiga, pendekatan actionnelle mendapat pengaruh yang cukup besar dari aliranfilasafat pragmatisme dan aliran filsafat analitik, khususnya analitik linguistic. Keempat, filsafat pendidikan pragmatisme dan analitik linguistik menjadi dasar filosofis metode Pembelajaran Bahasa Prancis sebagai bahasa Asing di Indonesia. 


\section{DAFTAR PUSTAKA}

Bagus, L. (1996). Kamus Filsafat. Jakarta: Gramedia.

Dwidjosusastro, S. et al. (1995). 50 Tahun Pendidikan di Indonesia. Jakarta: Humas Depdikbud.

Girardet, J. (2011). EnseignerLe Fle Selon Une Approche Actionnelle: Quelques Propositions Méthodologiques. Actes Du Xiième Colloque Pédagogique De L'alliance Française De São Paulo.

Girardet, J et J. Pécheur. (2008). Echo 1: Method de Français. Paris: CLE Internationale

Girardet, J et J. Pécheur. (2008). Echo 2: Method de Français. Paris: CLE Internationale

Girardet, J et J. Pécheur. (2008). Echo 3: Method de Français. Paris: CLE Internationale

Jazeri, M. (2010). Filsafat Analitik Bahasa: Pengertian, Perkembangan, dan Teoriteori Arti. Makalah Program Studi Pendidikan Bahasa Arab (PBA) Pascasarjana Institut Agama Islam Negeri Tulungagung.
Mustansyir, R. (2007). Filsafat Analitik: Sejarah, Perkembangan, dan Peranan Para Tokohnya. Yogyakarta: Pustaka Pelajar.

Nurlaila. (2012). Filsafat Ordinary Language dan Pembelajaran Bahasa.From http://ecampus.iainbatusangkar. ac.id/ojs/index.php/takdib/article/ viewFile/258/255

Piccardo, E. (2014). Du Communicative aL'actionnel: Un Cheminement De Recherche from http://www.edugains. ca/resourcesFSL/PDF/CommunicativeToActionApproach/CommunicativeToActionOriented_AResearchPathway_French.pdf.

Tagliante, C. (2002). L'évaluation et le Cadre Européen Commun. Paris: CLE International

Sadulloh, U. (2014). Pengantar Filsafat Pendidikan. Bandung: Penerbit Alfabeta

Wicoyo, A. J. (1997). Filsafat Bahasa Biasa dan Tokohnya. Yogyakarta: Penerbit Liberty. 